\title{
De héroes, naciones milenarias y guerras fratricidas. Tres mitos fundacionales en tres relatos historiográficos de la nación mexicana
}

\author{
Óscar Javier Linares Londoño1.
}

\section{Resumen}

La interpretación canónica de la independencia de México explica los hechos que van de 1810 a 1821 como la emancipación de la nación mexicana, pueblo milenario que remonta su identidad nacional a los mexicas, habitantes del Valle de México, antes de la llegada de los españoles. Por trescientos años el pueblo fue oprimido bajo el yugo español, y logra su independencia gracias al movimiento nacionalista de sus héroes.

Esta interpretación construida por los relatos historiográficos del siglo XIX, está basada en lo que llamaré los mitos fundacionales de la nación: el mito de la nación milenaria, el mito de los héroes y el mito de la pugna irreconciliable entre criollos y españoles. La historiografía decimonónica difundirá estos mitos con la firme intención de legitimar el movimiento independentista y de dotar de un relato homogéneo a la naciente nación.

\section{Palabras clave:}

mitos fundacionales, relato historiográfico, nación, independencia de México.

\section{Abstract}

The canonical interpretation of the independence of Mexico explains the facts that go from 1810 to 1821 as the emancipation of the Mexican nation, ancient nation that traced back its national identity to the Mexica people, inhabitants of the Valley of Mexico before the Spanish arrived. Oppressed for three hundred years under Spanish rule, the Mexican nation achieves its independence through nationalist movement of its heroes.

This interpretation, built by the nineteenth-century historiographical tales, is based on what we call the nation founding myths: the myth of the ancient nation, the myth of the heroes, and the myth of irreconcilable conflict between Creoles and Spanish. Nineteenth-century historiography will spread these myths with the firm intention of legitimizing the independence movement and give a consistent story to the emerging nation.

\section{Keywords:}

foundational myths, historiographic tale, nation, Mexican Independence.

Artículo recibido el 25 de julio de 2010 y aprobado el 30 de agosto de 2010

1 Licenciado en Ciencias Sociales de la Universidad Pedagógica Nacional, Filósofo de la Universidad Nacional de Colombia. En la actualidad cursa la Maestría en Estudios Latinoamericanos de la Universidad Nacional Autónoma de México. oscarjali@gmail.com 
"Hubiera deseado muchas veces que la pluma se convirtiera en espada".

Fray Servando Teresa de Mier

"La Nación Mexicana, que por trescientos años ni ha tenido voluntad propia ni libre el uso de la voz, sale hoy de la opresión en que ha vivido".

(Guedea, 2007, p. 182).

Las primeras palabras del Acta de Independencia de México, parecen no dejar lugar a dudas sobre el imaginario político de los independentistas en 1821. Según ellos, la "Nación Mexicana”, oprimida durante trescientos años, tenía su voluntad enajenada y su voz acallada; por tanto tiempo humillada, doblegada y abatida, se redime el 28 de septiembre de 1821, día en que se firma el Acta de Independencia, gracias a los "heroicos esfuerzos de sus hijos" (Guedea, 2007, p. 182).

Por fin ha llegado el esperado cese de la opresión, 18212, año que rememora ese imborrable 1521 en el que Cortés sojuzga a los mexicas justo 300 años atrás3 , será la fecha de refundación, o "Restitución", para usar las palabras del Acta de Independencia, de la "Nación Mexicana"; Restitución, es decir, restablecimiento del estado que antes se tenía.

No institución, que significaría la creación de algo absolutamente nuevo, pues la nación mexicana, como lo deja entrever el Acta de Independencia, preexistía a la canalla llegada española, sobrevivió a 300 años de colonialismo, y ahora, "arrollando obstáculos casi insuperables", por fin ve "consumada la empresa eternamente memorable": la refundación de una "nación soberana e independiente de la antigua España” (Guedea, 2007, p. 182).

2 Durante los primeros años del México independiente se celebró el 27 de septiembre de 1821, día de la consumación de la Independencia, como fiesta nacional; muy pronto, la fecha fue cambiada por el 16 de septiembre de 1810, día en que inicia la rebelión de Hidalgo. Las razones obedecen a la oposición frente al proyecto monarquista de Iturbide y al ensalzamiento, por parte de los liberales, de la insurgencia mexicana. Iturbide, otrora héroe de la Independencia, se convierte en villano. Hidalgo, otrora insurgente desalmado, asesino y sin plan político, se convierte en héroe; para este punto ver Rodríguez (2007).

3 Este hecho muestra cierto simbolismo de las efemérides, pues en 1821 emerge la nación que en 1521 había sido acallada.
A pesar de la aparente transparencia del imaginario político independentista, las preguntas que surgen sobre la fundación, o mejor, refundación, de la nación mexicana no son sencillas de abordar. En principio es necesario preguntar acerca de lo que se entiende por "nación" dentro de la expresión "Nación Mexicana”. En segundo lugar es menester cuestionar los motivos por los que se usa un discurso que da por sentado que la "Nación Mexicana" preexiste a la invasión española, sobrevive a trescientos años de colonización y, en 1821, renace para conseguir su independencia.

Responder la primera pregunta requeriría una larga disquisición teórica e histórica, habría que aclarar lo qué se entendía por nación en la tradición filosófico-política española y qué se está entendiendo por nación tras las revoluciones atlánticas. Es decir, se tendrían que mostrar los usos y transformaciones conceptuales de este vocablo que, justo hasta 1808, se empleaba principalmente para denotar a los habitantes de la Monarquía Hispánica, llamada hasta entonces "nación española", que, sin embargo, tras la crisis surgida por la invasión napoleónica, empieza a tomar otro rumbo, más restringido si se quiere ${ }^{4}$, primero con el uso del vocablo "nación americana" y luego, con acepciones aún más circunscriptas a determinados territorios coloniales, la "nación mexicana" por ejemplo, que correspondería al Virreinato de la Nueva España.

Esta problemática excede los objetivos de este ensayo, pero es necesario reconocer que es fundamental para entender la nación en Hispanoamérica como una invención de tipo moderno, ligada a la

4 Según Mónica Quijada (2003) "nación" tiene por lo menos tres usos diferentes durante el momento de la ruptura: la nación cultural, territorial e institucional. En el primer caso se trata de un uso principalmente colonial para designar "los distintos grupos étnicos que convivían bajo el gobierno común de la Corona de Castilla" (p. 209). Este uso aparece poco en el contexto independentista. En el caso de la nación territorial se trata de un uso enfocado en el territorio o la población asociada a un territorio. Aparece con mayor persistencia en la crisis monárquica aludiendo a los territorios de los virreinatos. Finalmente, la nación institucional está definida como el "nombre colectivo que significa algún pueblo grande, Reino, Estado, etc., sujeto a un mismo príncipe o gobierno" (p. 293), este uso no surgirá en Hispanoamérica hasta después de 1810 y se generalizará al final de la reconquista para identificar los nuevos gobiernos surgidos de la disolución de la monarquía. 
construcción y reconstrucción de las identidades colectivas de los pueblos que ocupaban dichos territorios 5 .

Con objetivos más concretos, lo que se propone en el presente trabajo es un acercamiento a una posible respuesta de la segunda pregunta: ¿qué objetivo se busca al narrar la "Nación Mexicana" como una nación milenaria, como una nación que tiene sus raíces en el más remoto pasado de los pueblos que habitaron lo que hoy son los Estados Unidos Mexicanos?

Este tipo de narraciones, que acá se llamarán mitos fundacionales de la nación, entendiendo por mito fundacional aquel relato o narración construido como arma historiográfica, cultural, educativa e ideológica, de lo que sería el prístino nacimiento de una sociedad, son imperantes en momentos de ruptura política. El rompimiento abrupto con un pasado que es necesario negar y la necesidad de empezar una Historia con un nuevo simbolismo, hacen de las revoluciones de Independencia un lugar ideal para encontrar algunos de estos mitos fundacionales en Hispanoamérica ${ }^{6}$.

No se trata de un problema meramente histórico, no viene al caso demostrar si existió o no, incluso si sigue existiendo o no, una "Nación Mexicana" milenaria, y de hecho no hay seguridad de que tal cosa pueda demostrase fácilmente. Sin embargo es posible pensar, siguiendo algunas investigaciones sobre el tema, y recalcando lo enmarañado del asunto, que ninguna nación, pueblo o sociedad, que podría haber preexistido a la conquista, esté liderando, en 1810 o 1821, la independencia de la Nueva España.

5 Para este punto remito a los estudios de Smith (1997) y (2000); y Miller (1997), además de la reconstrucción histórica del debate sobre la nación, con una adenda sobre el caso hispanoamericano, de Palti (2006).

6 Estos "mitos fundacionales" van a dar lugar a lo que Tomás Pérez Vejo (2010) llama el relato canónico de las independencias hispanoamericanas: "guerras de liberación nacional en las que las naciones americanas, esclavizadas por la nación española, consiguieron su independencia poniendo fin a tres siglos de colonialismo y explotación económica". (p.18). Es menester develar el carácter mítico de este relato canónico, ese es, en parte, el propósito de este ensayo.
Líderes como Agustín de Iturbide, cuya firma encabeza el Acta de Independencia, o Miguel Hidalgo, iniciador según Carlos María Bustamante del movimiento revolucionario, son, en el sentido pleno de la palabra, criollos, es decir españoles nacidos en América. Y como españoles, o herederos culturales y biológicos de los mismos, ni pudieron haber preexistido a la expansión europea en América, ni les interesa representar los intereses de grupos sociales y étnicos con los que no se sienten identificados, negros e indios por ejemplo.

El interés no es legitimar o deslegitimar la existencia de la nación milenaria como hecho histórico, sino entender los usos políticos, culturales e ideológicos de este tipo de narraciones, que además no se restringen a lo que acá hemos llamado el relato de la nación milenaria sino que, con la necesidad de darle fuerza al nuevo proyecto político, se complementan con otros mitos, como el relato de los héroes y el de la pugna irreconciliable entre criollos y peninsulares que también analizaremos en este ensayo.

Desde esta perspectiva, el sentido del relato de la nación milenaria ya había sido avizorado, de manera temprana, por Lucas Alamán, quien criticará esta manera de narrar el nacimiento de la nación mexicana al argumentar que:

No eran los restos de las naciones que antes dominaron en el país, las que promovían la independencia, ni ésta tenía por objeto reponerlas en sus derechos usurpados con la conquista, promovíanla los descendientes de los conquistadores, que no tenían otros derechos que los que les había dado esa misma conquista, contra la cual han declamado con una especie de frenesí imposible de explicar, como si fuesen los herederos de los pueblos conquistados y estuvieran en la obligación de vengar sus agravios (Alamán, 1985, p. 190).

Resulta paradójico el anacronismo de este tipo de relatos, pues muchos de los que se ven a sí mismos como oprimidos en 1821 fueron en realidad opresores antes de 1810, incluso hasta poco antes de 1821, como es el caso de Agustín de Iturbide, pero no es el objetivo, repito, entrar en esta polémica. Resulta más apropiado aclarar en qué sentido cabe el 
argumento de que se trata también de un problema ideológico-cultural.

Es evidente que lo que se está haciendo con este relato es en últimas inventar, en el sentido más fuerte del término, un tipo de identidad colectiva, específicamente nacional, que explica el origen de los mexicanos remontándose a tiempos anteriores a la conquista. Así, la nación mexicana sobrevivió a todos los ultrajes españoles durante 300 años de colonia y resucita, rememorando su legendario pasado, en la independencia.

Esta creencia repetida generación tras generación desde 1821, afianzada por el sistema educativo mexicano, tal vez se ha convertido en el principal mito fundacional de México como nación, a tal punto que decenas de años después de la declaración del Acta de Independencia, aún muchos mexicanos no sólo dan por sentada la existencia de dicha nación, sino que además se consideran como sus herederos y la siguen conformando.

Lo que queda claro es que la generación de la independencia se apropió del pasado de los pueblos que habitaron la región, desde las necesidades, problemas y urgencias de su presente. Se apropió no sólo en el sentido de tomar como propio lo ajeno, sino de inventar o construir un relato que permitiera nacionalizar la historia, legitimar sus nuevos gobiernos e impermeabilizar su proyecto de sociedad y nación.

Para avanzar en la comprensión de los usos ideológicos de estos mitos fundacionales se utilizarán tres de las principales historias sobre la Independencia de México escritas en el siglo XIX. Las historias o "relatos historiográficos"7, para usar la expresión de Guillermo Palacios, seleccionados son: La Historia de la Revolución de Nueva España, Antiguamente

7 Guillermo Palacios define el relato historiográfico contrastándolo con la profesionalización del campo histórico que tuvo lugar a finales del siglo XIX y principios del XX. Para Palacios el uso de relato historiográfico sobre historia, "permite diferenciar lo que parece ser un momento pre-moderno de la práctica de narrar el pasado [...] el relato es un arma con la que se reivindica un pasado que justifica las aspiraciones de determinados grupos o facciones, que descubren o inventan raíces, genealogías, y linajes que otorgan privilegios a unos y se los niegan a otros" (Palacios, 2009, p. 10). La narrativa del pasado es una vertiente de la lucha política decimonónica, de hecho será una de sus principales características.
Anáhuac, ó Verdadero Origen y Causas de Ella con la Relación de sus Progresos hasta el presente año de 1813 de José Guerra8, el Cuadro histórico de la Revolución Mexicana, comenzada en 15 de septiembre de 1810 por el ciudadano Miguel Hidalgo y Costilla, Cura del pueblo de Dolores, en el obispado de Michoacán de Carlos María de Bustamante, y la Historia de México desde los primeros movimientos que prepararon su Independencia en el año de 1808 hasta la época presente, de Lucas Alamán.

La selección tiene algo de arbitrario, como toda selección, porque grandes obras decimonónicas no están incluidas, como las de Lorenzo de Zavala o Vicente Rocafuerte ${ }^{9}$, pero esto también tiene una razón de ser. La Historia de Mier fue la primera historia de la revolución de Independencia, no sólo de México sino de toda Hispanoamérica, en ese sentido se trata de una obra que influyó a todas las posteriores ${ }^{10}$.

Por otra parte, el Cuadro de Bustamante y la Historia de Alamán representan la visión de cada uno de los grupos políticos que lucha por el poder en el México independiente. Bustamante dota de héroes y construye el andamiaje simbólico del proyecto político liberal: la nación milenaria, la insurgencia, los indios, Hidalgo y Morelos, el odio a los "gachupines". Mientras tanto, la Historia de Alamán hace lo propio en el caso del proyecto conservador: apología de la conquista, catolicismo, crítica a la Independencia, aceptación de españoles. Se trata de dos versiones historiográficas opuestas en las que se enfrentan dos proyectos diferentes de nación mexicana ${ }^{11}$.

Estas obras muestran la "necesidad de no pocos historiadores decimonónicos de explicar el surgimiento de la nación e incluso, de justificarlo" (Ávila y Guedea. 2007. p. 255), pues es la historia de este surgimiento y del papel de las élites en el mismo,

8 Servando Teresa de Mier firma su libro con su primer nombre "José" y su apellido materno "Guerra".

9 Para un panorama general de la historiografía del siglo XIX véase Annino y Rojas (2008).

10 Así lo atestiguan las numerosas citas y referencias a la Historia de Mier en las historias de Bustamante y Alamán.

11 Para una descripción de los dos proyectos de nación mexicana y de sus enfrentamientos políticos a lo largo del siglo XIX remito a Pérez Vejo (2009). 
lo que primero se debe concretar "como forma de justificar no tanto al Estado nacional sino a sus ocupantes [...] desdibujando la presencia de los adversarios y, sobre todo, de los grupos subalternos" (Palacios, 2009, p. 10).

Se trata, en sentido estricto, de un campo de batalla en el que se definen las identidades de los grupos que conformarán la nación, en el que se crean las lógicas de inclusión y exclusión de los diferentes grupos sociales y étnicos a los nuevos proyectos políticos ${ }^{12}$, en el que se busca justificar a las agrupaciones que ahora detentan el poder $y$ con el que se pretende borrar los vestigios de la anterior manera de organización social. Campo de batalla, para resumir, en el que se inventa la nación ${ }^{13}$.

La Independencia, como momento de ruptura política, estará definida por su naturaleza fundacional y mítica, caldo de cultivo de los relatos historiográficos decimonónicos y de la invención de mitos fundacionales. Los autores de estas historias son jueces vivientes del pasado imaginado, y participan de la construcción nacional haciendo una historia en la que se narran los hechos de acuerdo con las necesidades del presente, o se valora el pasado de acuerdo con las victorias o derrotas de sus proyectos.

\section{Los mitos fundacionales como construcciones ideológicas}

Los mitos fundacionales, difundidos en la prensa y por la naciente historiografía, son uno de los elementos fundamentales de la invención de las nuevas naciones; no es gratuita la explosión historiográfica y de prensa del siglo XIX, basta ver los numerosos tomos de las historias de Carlos María de Bustamante y Lucas Alamán ${ }^{14}$ como ejemplos.

Una de las preguntas de la naciente historiografía decimonónica será "qué hacer con ese pasado y ese presente de los antiguos pobladores del Anáhuac"

12 Los liberales, por ejemplo, incluirán a los indígenas (a su manera) pero excluirán a los españoles; por su parte los conservadores incluirán a los españoles pero excluirán a los indígenas.

13 Para este punto véase Palacios (2009).

14 El Cuadro histórico de La Revolución mexicana de 1810 de Bustamante tiene 8 tomos y la Historia de México desde los primeros movimientos que prepararon su independencia en el año 1808 hasta la época presente de Alamán tiene 5.
(Zermeño, 2009, p. 85). Paralelo a la invención de la nación hay que inventar también su historia: la historia de la nación, cierta historia de la nación, cierto "consenso historiográfico"15, como lo llaman los historiadores Manuel Chust y José Antonio Serrano.

La historia de la nación, que por momentos se confunde con la historia de la Independencia ${ }^{16}$, empezó a ser escrita desde 1813 con la obra de Mier, y a pesar de múltiples particularidades que no pueden perderse de vista, se puede afirmar que un conjunto de tesis sobre la nación, el pueblo y los héroes fueron defendidas desde Mier hasta la década de los años 50 del siglo $\mathrm{XX}^{17}$.

\section{La nación}

El patriotismo y el nacionalismo impregnaron a tal punto todas las explicaciones sobre el rompimiento con la metrópoli, que mutaron en un metarrelato omnipresente y fundacional. Según esta manera hegemónica de ver el proceso de la Independencia, ésta es explicada desde el convencimiento de estar analizando una gesta nacional, discurso que tuvo como propósito "unificar la historia de sociedades altamente diferenciadas étnica y socioeconómicamente, así como con amplios contrastes regionales"

15 Véase Chust y Serrano (2007)

16 "La historiografía patria del siglo XIX ha hecho de la formación de las Juntas de gobierno en América en 1810 la fecha clave de la Independencia: a la vez el acta de nacimiento de nuevas naciones y el principio de una época revolucionaria" (Guerra, 2006, p. 25).

17 A partir de este momento surge una nueva historiografía, más ligada a la investigación universitaria, que abre un sinnúmero de nuevos debates e interpretaciones en el campo académico, que no se relacionan con lo trabajado acá. Sólo se destacará el hecho de que con el nuevo consenso historiográfico se han reducido los estudios de los grandes hombres, ha surgido un fuerte interés por las particularidades del proceso (historia regional, por ejemplo) y se ha criticado la idea de la liberación nacional; mostrando entre otras cosas el impacto de las Cortes de Cádiz y del liberalismo doceañista en este proceso, abriendo nuevas líneas de investigación: elecciones, ciudadanía, realistas, vencidos. Los interesados pueden remitirse a los balances historiográficos de los últimos años. Véase Ávila y Guedea (2007); Chust y Serrano (2007). Es oportuno, además, mencionar que la nueva historia política sobre la Independencia está develando algunos de los mitos acá mencionados y recontando la historia de la independencia de México. Entre algunos de estos autores se puede mencionar a Guerra (2000); Eric Van Young (2010); Jaime Rodríguez (2005); Virginia Guedea (1992); Alfredo Ávila (2002) y Tomás Pérez Vejo (2010). 
así, la Nación Mexicana será el sujeto de la Independencia ${ }^{18}$, convirtiéndose en una especie de "feliz síntesis étnica, cultural, social y territorial" (Chust y Serrano, 2007, p. 10).

\section{El pueblo}

Para este consenso historiográfico el pueblo emerge como sujeto en la gesta independentista; la diversidad social, étnica y racial de la colonia desaparece o queda sumergida en las nociones de pueblo o ciudadanía defendidas por el liberalismo doceañista. Este pueblo homogéneo y sin fisuras encarna la lucha patriótica y compone la nación oprimida por 300 años, que ahora rompe el malvado yugo de España, la otra "nación" en lucha.

El pueblo es el revolucionario, el oprimido, bajo la noción de pueblo quedan difuminados o invisibilizados los otros proyectos de nación, y no está compuesto por el americano realista, sea este criollo o indígena ${ }^{19}$, sino por el sujeto revolucionario.

\section{El héroe}

El héroe tendrá el papel de iluminar el camino de la nación; emerge del pueblo, lidera sus gestas y encarna como ninguno los ideales nacionales, surge de la nación y para la nación "una nación romántica, ideal, de imágenes y realidades, de mitos inventados y de héroes construidos" (Chust y Mínguez, 2003, p. 9).

Los héroes son también construcciones históricas con las que se idealizan las cualidades y gestas de la vanguardia del pueblo, no siempre son figuras de consenso, y a lo largo de la historia las valoraciones y percepciones de los mismos pueden ser matizadas

18 Para Pérez Vejo (2010) es justamente esta interpretación la que es necesario empezar a cuestionar. "Para entender las guerras de independencia-dice-resulta imprescindible un marco interpretativo general que prescinda del análisis nacional. Uno de los problemas de los estudios sobre las guerras de independencia es que, con una visión teleológica y un anacronismo más que evidente, convierten a la nación en su objeto de estudio, en un momento en el que ésta ni existía, en un sentido moderno, ni jugaba ningún papel político relevante" (p. 26-27).

19 Para Chusty Serrano el caso indígena es más claro que el criollo, pues sencillamente los indígenas quedaron al margen de la Independencia por su ignorancia y alienación monárquica y católica, y por tratarse de una guerra entre criollos y españoles. por los acontecimientos del momento. Así, muchos héroes han terminado siendo villanos, y algunos villanos, héroes. En el contexto independentista son esenciales, ya que reemplazarán en el imaginario colectivo la imagen de los monarcas europeos.

Estas nociones-la nación, el pueblo y los héroes-representan un relato de la independencia maniquea "entre buenos y malos, entre patriotas y traidores, también entre vencedores y vencidos. Construcción de la nación que alumbró la historia patria" (Chust y Serrano, 2007, p. 11). Desde esta perspectiva se ha pensado la independencia y la invención de las identidades nacionales como algo natural, ineluctable, consecuencia necesaria de causas traslúcidas, cuando en realidad todavía es necesario desentrañar muchos de los hechos que acompañaron este periodo de la historia latinoamericana ${ }^{20}$.

Para el caso mexicano esta perspectiva se evidencia en la interpretación dominante de la Independencia según la cual el pueblo de México, cuya existencia bajo el dominio español no se ponía en duda: "tomó conciencia de su condición colonial y decidió, inspirado y dirigido por algunos criollos ilustrados, liberarse del despotismo trisecular, para adoptar una forma de gobierno republicana, liberal y federal, que era la que más le convenía" (Ávila y Guedea, 2007, p. 255).

Paradoja mayor, porque si la nación mexicana no existía, tampoco pudo haberse independizado. Este consenso historiográfico, aunque matizado y, en algunos casos, criticado fuertemente por la nueva historiografía, sigue ocupando un lugar predominante en el imaginario nacional sobre el surgimiento de nuestros países. Imaginario que lamentablemente está siendo reforzado por muchos de los discursos que a propósito del bicentenario están elaborando algunos de los gobiernos latinoamericanos ${ }^{21}$.

20 Desde hace varios años se ha insistido en este punto, por ejemplo para Brading (2009) "todavía es necesaria una cuidadosa investigación y paciente reflexión antes de que podamos distinguir la variada gama de precondiciones, precipitadores y simples disparadores de acción que se combinaron para producir la gran lucha por la Independencia" (p. 44).

21 Un ejemplo de ello es el Himno del Bicentenario creado por la Alta Consejería para la Independencia de Colombia. 
Pero en realidad lo que la nueva historiografía ha mostrado, y esto no puede perderse de vista, es el carácter teleológico de estas historias patrias. Se ha creído que:

Puesto que al final del proceso revolucionario aparecieron estados considerados como naciones y fundados en los principios políticos modernos, fue la precoz aspiración a la emancipación nacional y a las libertades modernas la que provocó la revolución y la Independencia (Guerra, 2006, p. 22).

Se ha tomado como causa de la ruptura lo que en realidad sólo es una consecuencia de la misma, que en muchos casos resultó tardía e inconclusa. La verdad es que, y esto lo ha mostrado muy bien Guerra, "la principal finalidad de estos relatos es justificar la ruptura” (Guerra, 2006, p. 33) y para este fin fue que se hicieron necesarios los mitos fundacionales difundidos en buena parte de los relatos historiográficos del siglo XIX.

Existió la conciencia de estar llegando a una nueva era, un nuevo momento histórico, de allí la necesidad de elaborar un nuevo relato sobre sus orígenes, de fijar un único y hegemónico pasado. Las Independencias serán el punto de partida de las historias nacionales, y esas historias representarán proyectos diferentes de nación, apropiaciones diferentes del pasado colonial y prehispánico ${ }^{22}$.

\section{Relatos historiográficos del siglo XIX: las historias de Mier, Bustamante y Alamán}

Servando Teresa de Mier escribe su Historia entre 1811 y 1813 en Cádiz y Londres. Protagonista de los ejércitos españoles durante la invasión napoleónica, hombre cercano a los diputados de las Cortes de Cádiz y habitante de un revolucionario ambiente

22 De todas maneras es necesario aclarar que el uso político del mito no es nuevo y no es exclusivo de esta coyuntura histórica. Se pueden rastrear mitos fundacionales en cada momento de quiebre histórico, eso sí, en todos los casos, cumpliendo la misma función: legitimar los nuevos proyectos políticos. Lo que resulta aún más interesante "es la fuerza de la reemergencia de mitos históricos como nueva fuente de legitimidad política" en la actualidad latinoamericana piénsese principalmente en el uso de Bolívar en la Venezuela de Chávez (Carrera, Leal, Lomné y Martínez, 2006, p. 13). político europeo, su obra tendrá un papel determinante en la construcción de algunos de los mitos nacionales mexicanos.

Mier ya había intervenido ampliamente en la realidad novohispana gracias al polémico Sermón Guadalupano, con el cual se había propuesto destruir la legitimidad de la conquista y colonización española basada en la predicación del evangelio. Para ello había negado la aparición de la Virgen de Guadalupe en la túnica de fray Diego y argumentó en favor de la evangelización de los indios americanos por el apóstol Tomás, mucho antes de la conquista.

Con estos argumentos se ponía en evidencia el arbitrio de la dominación española que tenía como principal argumento la evangelización. En la Historia, siguiendo esta línea de argumentación, también incluye una disertación para probar la predicación del evangelio antes de la conquista.

Además, Mier fue ampliamente conocido por su activismo político y editorial en Londres, en donde no sólo publicó su Historia sino que reeditó la obra de Bartolomé de las Casas, Destrucción de las Indias, poniendo en evidencia la influencia de éste sobre su pensamiento, pero sobretodo fue importante en la red de exiliados americanos a la que perteneció $y$ en la que se fraguaron muchos de los proyectos independentistas de América.

En su Historia discute entre otros, con López Cancelada, quien como redactor de la Gaceta de México, y enemigo de la revolución, había estado publicando argumentos que Mier se siente en la necesidad de deslegitimar. Entre otras cosas López Cancelada pidió que las Cortes eligieran diputados que representaran no a los criollos mexicanos sino a los españoles de México, porque los donativos de los peninsulares eran mayores que los de los criollos, Cancelada también critica las tácticas políticas que buscaban conseguir adeptos de la causa realista, por lo que Mier afirma que:

Más castigo merecía por las exhortaciones que hace al fin para que se despoje a los criollos de sus haciendas y posesiones y se restituya a los indios a quienes los conquistadores las usurparon: arenga muy a propósito en la boca de los insurgentes para revolver 
a los indios, pero que en la de Cancelada se dirige a unir éstos contra los criollos en favor de los europeos (MIER, 1986, p. XXIX).

Su Historia es un alegato a favor de la Independencia, o por lo menos de cierta autonomía, y se constituyó en el principal faro contra las versiones realistas de la insurgencia. No por nada es reconocido como "el primer historiador de la insurgencia mexicana y su historiador más original" (Brading, 2009, p. 44). Su argumento principal está desarrollado en el libro XIV de su Historia, en donde construye la idea de un antiguo pacto entre españoles y americanos, la magna carta hispanoamericana, que había servido de constitución entre los conquistadores y los reyes, y que ahora está siendo anulado por el despotismo monárquico que pretende ver a América como una mera colonia, desconociendo su fundacional carácter de Reino ${ }^{23}$.

Se dice que su Historia fue tan influyente que convirtió a Iturbide de realista en insurgente. Por lo menos así lo cree Bustamante, para quien Iturbide encontraría en la Historia de Mier el deshonroso lugar que se le daba en el cuadro de la historia patria, pues Mier hablaba de las ejecuciones sangrientas a prisioneros americanos que ordenó en la batalla del Puente de Salvatierra en 1813, con lo que Iturbide:

Juró desde aquel instante borrar con hechos hazañosos aquella negra mancilla. Tal fue la causa de esta instantánea y saludable conversión [...] ¡Mier! divino Mier, he aquí el fruto más sazonado de tu buen celo [...] tu patria es libre a merced en parte de tus afanes (Bustamante, 1985, p. 11).

Para David Brading, reconocido investigador de la historia de México, Fray Servando "con la ayuda de su amigo y discípulo, Carlos María de Bustamante, logró fusionar una ideología nacionalista que atribuía las causas de la Independencia a los acontecimientos del siglo XVI" (Brading, 2009, p.

23 Alamán (1985) critica fuertemente esta idea de la carta magna americana pues "estos contratos para la conquista, en donde los hubo, eran meramente personales con los conquistadores, no había ya parte que tuviese derecho a reclamarlos" (p. 189).
44). Bustamante, quien en 1805 fue editor del Diario de México, desde 1810 se enrola con los insurgentes encabezados por Hidalgo, y en 1812 funda El Juguetillo, uno de los pocos diarios rebeldes.

Bustamante además participa en 1814 en el experimento constitucional de Apatzingán, está en prisión de 1817 a 1820, en 1821 funda La Abispa (sic) de Chilpancingo y en diversas ocasiones es diputado del gobierno independiente, es uno de los personajes centrales en la construcción del imaginario nacional mexicano. Escribe su Cuadro entre 1821 y 1827, publicado en un periódico por entregas semanales y posteriormente editado en varios volúmenes entre 1843 y $1846^{24}$.

Aunque se critique a Bustamante por el poco rigor documental, el apasionamiento y lo fantasiosa de su escritura, críticas de las que su Cuadro no sale exento, fue "el primero en darse cuenta de la necesidad de inventar un imaginario patriótico coherente para sustentar el México independiente" (Annino y Rojas, 2008, p. 34) y por ello su obra histórica se convierte en el principal pilar del proyecto de invención de la nación mexicana.

Bustamante era consciente de la tarea que estaba desempañando, por ello afirma en el prólogo de su Cuadro: "he erigido un monumento muy estimable de memorias que podrán servir como el primer cimiento sobre el que se levante el edificio histórico de la revolución mexicana" (Bustamante, 1985, p. v). Primer cimiento que en muchos aspectos sigue siendo el único.

Este papel del Cuadro de Bustamante se puede evidenciar de manera muy clara en la invención del relato de la nación milenaria; aunque el mito aparece de manera explícita en el Acta de Independencia, será el Cuadro Histórico el primero en difundirlo. Según Annino, Bustamante "presentó a México como una patria que perdió su libertad bajo el 'despotismo' colonial, que la recuperó con la independencia y que la consolidó con la república" (Annino y Rojas, 2008, p. 34).

24 Para una visión de la obra de Bustamante en la historiografía mexicana, véase el artículo "El historiador don Carlos María de Bustamante ante la conciencia histórica mexicana" de Ortega y Medina (1973). 
Su obra se constituyó así en un parámetro con el que se midió la historiografía sobre la independencia del siglo XIX y XX, "la misma idea de revolución, en el sentido de un proceso irreversible que funda no sólo un nuevo régimen sino también una nueva identidad colectiva, se debe a Bustamante" (Annino y Rojas, 2008, p. 39)25. El Cuadro representa por primera vez el nexo causal entre Independencia y patria, al tiempo que a Morelos como punto de equilibrio entre Hidalgo e Iturbide.

Por su parte Lucas Alamán, víctima prematura de la violencia insurgente siendo aún joven-a los 18 años presenció la masacre de la Alhóndiga de Granaditas-26, testigo del pensamiento revolucionario europeo en sus travesías por el Viejo Continente, diputado ante las Cortes españolas después de la revolución de Riego, fundador del partido conservador mexicano, defensor del proyecto monarquistaprincipalmente tras la derrota mexicana en la guerra con los Estados Unidos-y figura clave de la política mexicana hasta su muerte en 1853, legará una Historia de México que para muchos sigue siendo la más rigurosa ${ }^{27}$.

Por lo mismo será Alamán quien ponga al descubierto algunos de los mitos fundacionales de la nación mexicana, como el de la nación milenaria, relato inventado por el Cuadro de Bustamante y por el liberalismo mexicano. Aunque también será quien construya con mayor énfasis otros de los mitos de la nación mexicana como la pugna irreconciliable entre españoles y criollos; también tuvo su propio proyecto de nación, el de la nación conservadora,

25 Incluso revolución se puede entender desde Bustamante en su otra acepción: como giro, vuelta, como ese re-volver a la prístina nación mexicana.

26 Hijo de una importante familia de Guanajuato su visión de la Independencia estará constantemente marcada por los violentos hechos que tuvo que presenciar en su ciudad natal cuando era niño. Por los vínculos de su familia había conocido a Hidalgo antes de 1810, principalmente como interlocutor del Intendente Riaño, quien años después será su principal enemigo.

27 A pesar de que su militancia conservadora le ha valido muchas críticas desde la historiografía liberal imperante en el México decimonónico, su Historia ha logrado consolidarse como la más completa y acabada. Para Antonio Annino (2008), por ejemplo, su Historia "es todavía la mejor obra de la época y, quizás, de todo el siglo XIX" (p. 58). que fracasará prematuramente en la segunda mitad del siglo XIX mexicano.

\section{El mito fundacional de la nación milenaria}

Bustamante, como ya mencionamos, jugará un papel central en la construcción de los mitos fundacionales de la naciente nación mexicana, principalmente con la invención del relato de la nación milenaria y la creación de un panteón de héroes nacionales, en la que los insurgentes y los antiguos gobernantes indios tomarán el papel central.

A pesar de las críticas, del conservatismo y de cierta ala liberal, a los insurgentes por la violencia descomunal de su movimiento durante la independencia, las razones que Bustamante elabora para justificar los actos de Hidalgo, Morelos y sus tropas siguen siendo esenciales en la narración sobre la independencia mexicana: los hechos revolucionarios iniciados en Dolores se explican porque la conquista trajo consigo la usurpación de la libertad y por el despotismo colonial español. Se trata, en últimas, de la venganza de la "nación mexicana", un ajuste de cuentas justo y necesario.

Aunque la independencia fue liderada por criollos $^{28}$, que en nada se diferenciaban de los españoles de los que pretendían separarse, Bustamante hace creer que la "nación mexicana", construcción abstracta e ideológica de su relato historiográfico se remonta, por lo menos al siglo XIV. Después de siglos de sojuzgamiento esta nación está por fin rompiendo las cadenas a las que había sido sometida por la Monarquía española, y es la antigua "nación mexicana" la que se está alzando.

Lo que hace este mito fundacional es trazar una línea de continuidad entre las poblaciones originarias, la sociedad colonial americana y los criollos del siglo XIX. Esta construcción historiográfica se manifiesta en las palabras que Bustamante usa a propósito del ataque de la Alhóndiga de granaditas en Guanajuato:

Sorprendióme el sueño meditando sobre ella (la Alhóndiga de Granaditas), y se me figuró que veía

28 Para la construcción de la noción de "criollo" como opuesto a español véase Pérez (2009). 
entre aquellos cadáveres y miembros palpitantes, a los genios de Cortés, de Alvarado y de Pizarro, que se mecían despavoridos observándolos, y que lanzándose llorosa sobre ellos la América con voz terrible les decía... ¿De qué os horrorizáis a vista de estas víctimas? ¿Habéis olvidado las crueles matanzas que hicisteis tres siglo ha en Tabasco, en Cholula, en el templo mayor de México, en Cuernavaca?... ¿Han desaparecido de vuestra memoria las ejecuciones de Cuauhpopoca, a quien quemasteis vivo? ¿El arresto de Motheuzoma, a quien debiendo la hospitalidad más generosa, y que os cargase y abrumase con el peso de innumerables riquezas y tesoros, prendisteis en su mismo palacio, violando el sagrado derecho de la hospitalidad y por último le quitasteis a puñaladas la vida? [...] ¿Ignoráis acaso que en la balanza del gran Teotloquenahuaque se pesaron estos crímenes, y que reservó su venganza para mis abatidos y esclavizados hijos, después de tres centurias de años? (Bustamante, 1985, p. 42).

El mensaje es claro. Bustamante no se lamenta de las decenas de cuerpos españoles que yacen sin vida en este enfrentamiento, no puede hacerlo porque los españoles tampoco tuvieron compasión con los miles de indios asesinados durante la conquista. Se trata de un acto justo de venganza. Los abatidos 300 años atrás ahora levantan sus armas para salir de la esclavitud; la balanza del gran Teotloquenahuaque vuelve a estar nivelada. Por ello Bustamante da tan importante paso, identificar a los insurgentes con "los vencidos, con los indios, antiguos poseedores del territorio y presentar la lucha por la Independencia como una revancha de la conquista" (Guerra, 2006, p.31).

Bustamante justifica con su relato los excesos de la Independencia, limpiando de toda culpabilidad las consciencias de los españoles americanos que han asesinado a sus hermanos. Para ello crea un malentendido, una confusión, una construcción ideológica. El proceso independentista es visto como un movimiento de emancipación nacional pues:

Al seguir un esquema de "nación" en cuanto a la formación del Estado-nación, los estados hispanoamericanos son concebidos como la expresión de nacionalidades que, por medio de la independen- cia, conquistaron su existencia autónoma en tanto naciones soberanas" (Guerra, 1997, p. 98).

Los problemas de esta concepción son evidentes, pero se pueden resumir en la ausencia de un movimiento nacionalista antes de la independencia. ¿Qué tipo de nación es la "Nación Mexicana" en 1810 o 1821? Guerra las calificará como "nacionalidades mudas” (1997, p. 99), construcciones ideológicas sin ningún asidero real.

\section{El mito fundacional de lo heroico}

La nación necesita sus héroes, hombres que con sus gestas sean la punta de lanza de los nuevos proyectos políticos latinoamericanos. Lo heroico es visto "como acto fundacional" (Palacios, 2009, p. 11) de las nuevas sociedades, figuras como Hidalgo, Morelos o Iturbide encarnarán los ideales de la "Nación Mexicana”, interpretarán las necesidades del pueblo, tras el devastador sojuzgamiento español, y liderarán el proceso justiciero independentista.

No importó que Hidalgo nunca proclamara la independencia, dirigiera de manera muy poco organizada sus ejércitos o luchara bajo la bandera de Fernando VII. La historiografía oficial lo ha elevado a gestor de la independencia nacional, incluso por encima de Morelos, Guerrero e Iturbide ${ }^{29}$. Se trata por supuesto de la invención del héroe de la nación, pues como bien lo señala Annino:

Había que imaginar y escribir una historia de los orígenes de la nación mexicana en términos radicalmente distintos, como una historia revolucionaria, identificada más con las rupturas que con las continuidades, con los héroes más que con las instituciones honorables (Annino y Rojas, 2008, p. 28).

Como ya se ha mencionado, el primero en darse cuenta de la necesidad de escribir esta historia, de inventar este imaginario patriótico, de construir el

29 Es revelador el hecho de que la fiesta nacional mexicana sea el 16 de septiembre, día del levantamiento de Hidalgo, y no el 27 de septiembre, día de la consumación de la Independencia; para ser más exactos la fiesta nacional era el 15 de septiembre, pero Juárez la cambió un día para hacerla coincidir con su natalicio. 
panteón nacional, será el propio Bustamante, quien, aunque a veces crítico de Hidalgo, exaltará sin reserva el papel de la insurgencia mexicana. Por ello uno de sus objetivos en el cuadro fue "hacer que la posteridad, más justa que la generación presente, aprecie en sus quilates el mérito y virtud de los primeros hombres a quienes debemos la independencia" (Bustamante, 1985, p. 18).

Principalmente Hidalgo y Morelos encarnan la heroicidad patria mexicana, y son los creadores del simbolismo nacional: Hidalgo al enarbolar como bandera de los insurrectos una imagen de la Virgen de Guadalupe, Morelos al elevar "a los dirigentes indígenas que defendieron sus pueblos ante las tropas de Hernán Cortés al sitial de héroes de la patria" (Florescano, 2002, p. 292), fundiendo el culto de estos antiguos héroes indígenas con los nuevos héroes del movimiento insurgente.

Así, Morelos, en la apertura del Congreso de Chilpancingo de 1813, se refiere a lo que va a llamarse México por su antiguo nombre: Anáhuac, e invoca a los antiguos héroes, llamados ahora "Genios" para celebrar con ellos "el fausto momento en que vuestros ilustres hijos se han congregado para vengar vuestros ultrajes y desafueros y librarse de las garras de la tiranía" (Florescano, 2002, p. 293).

Los genios invocados por Morelos fueron Moctezuma, Cacama, Quautimozin, Xicoténcatl y Caltzontzin. Lo que Morelos aún no alcanzaba a avizorar era que, pocos años después, él y el mismo Hidalgo, serán también invocados por la nueva nación mexicana en cada conmemoración de la Independencia ${ }^{30}$. En conclusión, con el movimiento insurgente nace un nuevo proyecto político e histórico que creará y recreará sus propios símbolos, héroes y anclajes políticos.

El caso de Hidalgo es más polémico que el de Morelos, debido a que a pesar de su omnipresencia en la imaginería política mexicana, su memoria ha sido controvertida porque el periodo en el que encabezó los ejércitos insurgentes fue también el

30 Fue también Morelos quien por primera vez coloca el antiguo emblema del Águila y el Nopal en una bandera insurgente, y lo llamó el “gran sello de la nación” (Florescano, 2002, p. 293). momento de mayor sevicia en las tropas patrióticas, de hecho "Hidalgo fue celebrado mucho más en las ceremonias cívicas, en los discursos y en la prensa que en la obras históricas de la época" (Annino y Rojas, 2008, p. 58). Bustamante, por ejemplo, después de rescatar las virtudes de Hidalgo, y a pesar de enfatizar desde el título de su Historia que es el iniciador de la revolución, afirma que:

Las deturpó [hablando de sus virtudes] con diversos rasgos de crueldad [...] en su corazón habita un depósito de odio, tal vez concebido desde que vio que su feligresía quedó reducida a la miseria por la bárbara disposición de que no elaborasen vinos con el producto de sus viñas [...] Hidalgo hizo mucho, pero pudo haber hecho más; si hubiera tenido el carácter de aquel Morelos que sacaba oro del mismo estiércol, la América habría conseguido la Independencia a vuelta de seis meses, economizándose mucha sangre (Bustamante, 1985, p. 264-266).

Lucas Alamán es mucho más equilibrado en sus juicios, aunque también crítica a Hidalgo, es respetuoso con Morelos e incluso crítico de Iturbide ${ }^{31}$; elabora un perfil casi psicológico de Hidalgo, afirma que le llamaban "zorro" por su carácter taimado, aunque pueda entenderse también que el apelativo se refiera a la poca severidad de sus costumbres y la poca ortodoxia en sus opiniones. La mayor crítica a Hidalgo está relacionada con la tendencia al saqueo y la barbarie de su movimiento:

No es extraño que en un pueblo en que por desgracia la religión estaba casi reducida a puras prácticas exteriores; en que muchos de sus ministros, particularmente en poblaciones pequeñas, estaban entregados a la vida más licenciosa ${ }^{32}$ : cuando el vicio dominante en la masa de la población es la propensión al robo, hallase tan fácilmente partidarios una revolución cuyo primer paso era poner en

31 Tal vez más crítico que el mismo Bustamante, para quien "Iturbide será grande porque fue dócil, y más grande aún, porque oyendo la voz de su patria, y correspondiendo a su llamamiento, empuñó la espada, desafió a la muerte, y colocó sobre el antiguo Tenochtitlán el pendón augusto de nuestra libertad política". (Bustamante, 1985, p. 11).

32 Probablemente refiriéndose a Hidalgo. 
libertad a los criminales, abandonar las propiedades de la parte más rica de la población a un ilimitado saqueo, sublevar a la plebe contra todo lo que hasta entonces había temido o respetado, y dar rienda suelta a todos los vicios (Alamán, 1985, p. 380).

La revolución iniciada por Hidalgo tendrá para Alamán la responsabilidad de haber destruido los cimientos del edificio social, de sofocar la moral, la justicia y la virtud, y de ser el origen de todos los males de la nación mexicana. No hay riesgo en aventurar que de haber sido el proyecto político de Alamán el imperante en México, Hidalgo no ocuparía el lugar que ahora ocupa.

Para Ortega y Medina "todo el mundo sabe quiénes son los padres de la Independencia, pero la unanimidad de la aceptación, que hoy nos parece obvia, sólo podía ser alcanzada mediante la reiteración clamante del historiador, actor y testigo de la insurgencia” (Ortega y Medina, 1973, p. 20): don Carlos María. Serán las oraciones cívicas, la prensa, la educación y, en un lugar no poco importante, la historiografía, las encargadas de conseguir dicha unanimidad.

Lo alarmante de la visión de Ortega y Medina es que defendiendo a Bustamante del examen al que lo somete Tornel ${ }^{33}$, afirmen que la atroz crítica a Bustamante en el siglo XIX será recompensada por la exaltación de su obra, o mejor de su visión de la insurgencia tras la Revolución mexicana de 1910 y que:

Hemos, por tanto, de agradecer a Bustamante su ardoroso empeño, que hizo y hace posible la inspiración historiográfica democrática y popular, y que permitió y permite aún la orientación y puesta en marcha de gran parte de los sueños e ideales nacionales de antaño (Ortega y Medina, 1973, p. 36).

De nuevo aparece desnuda la politización de la historiografía, la justificación de los mitos fundacionales y la expansión del panteón heroico, en este caso añadiendo a Bustamante y a los insurgentes de 1910.

33 Para Tornel, Bustamante hacía de cada insurgente un héroe.

\section{El mito fundacional de la pugna entre criollos y peninsulares}

El tercer y último mito fundacional está íntimamente relacionado con el relato de la nación milenaria. Se trata de la construcción ideológica o elaboración historiográfica (Pérez Vejo, 2009, p. 18) de la oposición español-criollo como explicación de la independencia de la Nueva España. La pregunta de fondo sigue siendo ¿cuáles son las causas de la revolución de independencia?, y respuestas no han sido pocas, pero el consenso historiográfico ha vuelto hegemónicas algunas respuestas, un buen ejemplo es la oposición entre criollos y peninsulares, que se ha mostrado como el gran catalizador de la lucha por la independencia.

Evidentemente el enfrentamiento existió, pero teniendo en cuenta que los peninsulares tan sólo constituían el $2 \%$ de la población total en 1810 , y que tanto los ejércitos realistas como los criollos estuvieron integrados casi totalmente por americanos, vale la pena pensar hasta dónde se trató de una guerra entre la "Nación Mexicana" y la "Nación Española", cuando todo apunta más bien a que fue una guerra civil, entre criollos americanos con proyectos de sociedad y nación distintos.

En ese sentido la invención del relato de la pugna entre criollos y peninsulares en realidad está encubriendo la guerra fratricida de independencia. No se trataba, entonces, del alzamiento de una mítica nación mexicana que difumina sus orígenes en la larguísima historia del Valle de México, sino de la negación de la identidad española en el nuevo proyecto nacional, de una guerra civil en la que se intenta ocultar la manera en que hermanos hispanoamericanos se están quitando la vida por acceder al poder político de los nuevos gobiernos instaurados o por instaurar.

El primero en narrar el relato de la pugna entre criollos y peninsulares como explicación de la lucha por la independencia fue Mier. Fray Servando identificó, de hecho, la guerra hispanoamericana por la independencia como una guerra entre España y América, ocultando los componentes de guerra civil entre los mismos americanos; la causa de esta pugna se encuentra, según Mier, en la invasión napoleónica. 
Tras la crisis monárquica, España se verá forzada a cambiar la actitud para con América, convirtiendo los territorios, que hasta ayer eran reinos, en odiosas colonias, faltando al fundador pacto social entre las dos, negando la constitución que había mantenido en armónica convivencia las dos partes del Atlántico. La originaria carta magna muta ahora en la absoluta dependencia, incluso en el probable caso de caer bajo dominio francés. La cancelación de aquel pacto originario será el origen de la guerra por la independencia.

En la Historia de Bustamante también aparece esta construcción ideológica, Bustamante le otorga un importante papel en su Historia al proyecto juntista de 1808 en Ciudad de México. La propuesta de instalar una junta y convocar a cortes en todo el reino, realizada por Francisco Primo de Verdad y Ramos, Juan Francisco Azcárate y el ayuntamiento, va a recibir una recia oposición por parte de la Audiencia, que terminará con el arresto del Virrey Iturrigaray, cercano a la causa juntista.

La detallada descripción de estos hechos por parte de Bustamante muestra su empeño en encontrar los detonantes de la revolución que encabezará Hidalgo. La prisión del virrey evidenciará la falta de escrúpulos de la Audiencia, pues Iturrigaray no sólo es juzgado por la inquisición bajo cargos de herejía, con el fin de "engañar al pueblo con lo que más ama que es la religión para evitar su alarma" (Bustamante, 1985, p. 15), sino que además atribuirá acciones fácilmente concentradas en algunos individuos, al pueblo mexicano, vilipendiando la imagen viva del rey en Nueva España; la consecuencia no puede ser más clara:

Desde aquel momento, y por tan escandalosa agresión quedan rotos para siempre los lazos de amor que habían unido a los españoles con los americanos [...] desde esta época aparecieron ya los síntomas de una revolución estragosa, y de un odio general que hervía en los corazones de todos. El reino estaba volcanizado, y a punto de estallar con una detonación horrísona (Bustamante, 1985, p. 15-16).

Por su parte, la preferencia en los empleos públicos y beneficios eclesiásticos fue, para Alamán, el motivo principal de la rivalidad entre criollos y peninsulares. La clase española, como él la llama, es la predominante en empleos, ilustración, privilegios y riqueza, sólo ella dispone de derechos políticos y civiles.

Incluso, afirma Alamán, "aquellos con el poder y la riqueza eran a veces más favorecidos por el bello sexo" (1985, p. 14), situación no poco importante, teniendo en cuenta que como argumenta el historiador conservador, las mujeres en América "valían más que los hombres" (1985, p. 14), dado que todas las mujeres blancas eran criollas. De esta manera, concluye, la "división entre europeos y criollos fue la causa de las revoluciones" (Alamán, 1985, p. 20) ${ }^{34}$. La pugna entre criollos y peninsulares aparece en Alamán más enfáticamente que en Mier y Bustamante. Para Alamán el movimiento insurgente no tenía:

Uniformidad de miras ni un plan concertado, ni aún una idea clara de lo que se pretendía hacer: se deseaba vagamente la independencia, como un medio de hacer recaer todos los empleos en los americanos y de apoderarse de la administración pública” (Alamán, 1985, p. 276).

Este odio se presenta claramente en el inicio de la Revolución en Dolores cuando, según Alamán, al descubrirse la conspiración, Hidalgo dijo: "caballeros, somos perdidos, aquí no hay más recurso que ir a coger gachupines [...] ya Uds. habrán visto este movimiento: pues sepan que no tiene más objeto que quitar el mando a los europeos" (Alamán, 1985, p. 374-376).

Uno de los investigadores que ha mostrado con mayor fuerza el uso ideológico de la pugna entre criollos y peninsulares es Tomás Pérez Vejo. En su libro España en el debate público mexicano, 1836-1867. Aportaciones para una historia de la nación, explica que dicha disputa, tan enconada en las primeras décadas de la nación mexicana, tiene su origen en

34 Podríamos decir que en Bustamante los hechos de 1808 son los que desencadenan este odio y que en Alamán el odio preexiste y explica lo ocurrido en el proyecto juntista de Azcárate y Primo de Verdad. Esto se evidencia en la presentación que hace Alamán de estos sucesos como un plan enmascarado de independencia y de la Junta Nacional que ejercería la soberanía como el pretexto para conseguir dicho plan. 
una construcción ideológica, principalmente de los relatos historiográficos decimonónicos.

El argumento central de Pérez Vejo se basa en la explicación del proceso de invención de la nación mexicana como proceso sui géneris diferente del europeo, que ha sido el punto central de este tipo de análisis; para Pérez Vejo todos los procesos de invención de la nación, entendidos como procesos de construcción de identidades colectivas, "llevan implícito un proceso de invención del otro" (Pérez Vejo, 2009, p. 10).

Regularmente ese otro está afuera, es externo a la comunidad en construcción, pero en el caso mexicano, y más generalmente hispanoamericano, "la construcción-invención de las nuevas naciones fue llevada a cabo por los descendientes biológicos y culturales de los antiguos colonizadores y conquistadores" (Pérez Vejo, 2009, p. 10). Es decir, el otro, el extranjero, el extraño, el enemigo, era el mismo constructor-inventor de la nación, el patriota, el nacionalista.

Esta tensión traerá sus propias consecuencias: los constructores de la nación no podían expulsarse a sí mismos, tenían la necesidad de separarse del otrosí-mismo, pero no podían hacerlo proclamando un idioma, religión o tradición diferente de la suya. La única opción posible fue "inventar a los españoles", es decir, crear lo que Pérez Vejo llama la leyenda dorada del nacionalismo: "había unas naciones oprimidas por un imperio colonial que se sacudieron el yugo de la dominación y, cual bellas durmientes, despertaron un día a la luz de la libertad" (Pérez Vejo, 2009, p. 11).

En ese sentido, el enfrentamiento entre criollos y peninsulares es una construcción ideológica clave en el proceso de construcción nacional, "no estamos ante un enfrentamiento metafísico entre naciones, representadas por criollos y peninsulares, sino ante el reto de negar la nación tradicional para construir la nación moderna" (Pérez Vejo, 2009, p. 12). La paradoja identitaria de esta generación fue clara: se acostaron un día siendo españoles frente a indios y castas, y al levantarse, de repente, eran mexicanos frente a los españoles; por ello, para Pérez Vejo:

La guerra de independencia vista como un enfrentamiento entre criollos y peninsulares es esencialmente una forma de propaganda política de los insurgentes, una construcción ideológica forjada en medio del conflicto como un arma de lucha más; también una elaboración historiográfica que permite ocultar los componentes fratricidas del conflicto (Pérez Vejo, 2009, p. 18).

Pues como dice Annino "en México, la guerra entre insurgentes y realistas fue una lucha básicamente entre mexicanos" (Annino y Rojas, 2008, p. 28).

Para concluir me gustaría regresar a la queja de Mier que aparece como epígrafe del presente texto: "hubiera deseado muchas veces que la pluma se convirtiera en espada". En realidad, creo que Mier no valoró suficientemente el papel que su Historia y que los demás relatos historiográficos decimonónicos tuvieron sobre los procesos de invención de la nación.

Como hemos visto, los relatos historiográficos jugaron un papel determinante en la invención y legitimidad de las nuevas naciones, que en el caso mexicano, aún enarbolan a Hidalgo y a los mexicas. Por ello mismo habría que replicarle a Mier que su pluma fue más espada de lo que él se hubiese imaginado, pues la pluma de los relatos historiográficos fue la espada de la vanguardia nacionalista.h 


\section{Bibliografía}

Alamán, L. (1985). Historia de México desde los primeros movimientos que prepararon su independencia en el año de 1808 hasta la época presente. México: Instituto Cultural Helénico, Fondo de Cultura Económica.

Annino, A. y Rojas, R. (2008). La independencia. México: CIDE, Fondo de Cultura Económica.

Ávila, A. (2002). En nombre de la nación. La formación del gobierno representativo en México, 1808-1824. México: Taurus, CIDE.

Ávila, A., y Guedea, V. (2007). 'De la independencia nacional a los procesos autonomistas novohispanos: balance de la historiografía reciente'. En Chust, M., y Serrano, J. A. (Eds.) Debates sobre las independencias iberoamericanas. Madrid: Ahila, Iberoamericana.

Ávila, A. y Guedea, V. (2007). La Independencia de México: temas e interpretaciones recientes. México: Universidad Nacional Autónoma de México, Instituto de Investigaciones Históricas.

Brading, D. (2009). Los orígenes del nacionalismo mexicano. México: Ediciones Era.

Bustamante, C. (1985). Cuadro histórico de la Revolución mexicana comenzada en 15 de septiembre de 1810 por el ciudadano Miguel Hidalgo y Costilla, Cura del pueblo de los Dolores, en el obispado de Michoacán. México: Instituto Cultural Helénico, Fondo de Cultura Económica, Instituto Nacional de Estudios Históricos de la Revolución Mexicana.

Chust, M., y Mínguez, V. (2003). La construcción del héroe en España y México (1789-1847). Valencia: Universidad de Valencia.

Florescano, E. (2002). Historia de las historias de la nación mexicana. México: Taurus.

Guedea, V. (1992). En busca de un gobierno alterno: los guadalupes de México. México: Universidad Nacional Autónoma de México, Instituto de Investigaciones Históricas.

Guedea, V. (2007). Textos insurgentes (1808-1821). México: Universidad Nacional Autónoma de México.

Guerra, F. X. (1997). 'La nación en América hispánica. El problema de los orígenes'. En Gauchet, M., Manent, P., y Rosanvallon, P. Nación y modernidad. Buenos Aires: Nueva Visión.
Guerra, F. X. (2000). Modernidad e independencias. Ensayos sobre las revoluciones hispánicas. México: Mapfre, Fondo de Cultura Económica.

Guerra, F. X. (2006). 'La ruptura originaria: mutaciones, debates y mitos de la independencia. En Carrera, D., Curiel, L. C., Lomné, G., y Martínez, F. Mitos políticos en las sociedades andinas. Orígenes, invenciones y ficciones. Caracas: Editorial Equinoccio, Université de Marne la Vallée, Instituto Francés de Estudios Andinos.

Mier, S. T. (1986). Historia de la Revolución de Nueva España, Antiguamente Anáhuac, ó verdadero origen y causas de ella con la relación de sus progresos hasta el presente año de 1813. México: Instituto Cultural Helénico, Fondo de Cultura Económica.

Miller, D. (1997). Sobre la nacionalidad: autodeterminación y pluralismo cultural. Barcelona: Paidós.

Ortega y Medina, J. (1973). Estudios de tema mexicano. México: Sepsetentas.

Palti, E. (2006). La nación como problema. Los historiadores y la "cuestión nacional". Buenos Aires: Fondo de Cultura Económica.

Palti, E. (2009). 'La nación argentina entre el ser y el acontecimiento. La controvertida plasmación de una visión genealógica del pasado nacional'. En Palacios, G. La nación y su historia. Independencias, relato historiográfico y debates sobre la nación: América Latina, siglo XIX. México: El Colegio de México.

Pérez Vejo, T. (2008). España en el debate público mexicano, 1836-1867. Aportaciones para una historia de la nación. México: Colegio de México, Escuela Nacional de Antropología e Historia, Instituto Nacional de Antropología e Historia.

Pérez Vejo, T. (2010). Elegía criolla. Una reinterpretación de las guerras de independencia hispanoamericana. México: Tusquets.

Quijada, M. (2003). ¿¿Qué nación? Dinámicas y dicotomías de la nación en el imaginario hispanoamericano' En Annino, A., y Guerra, F. X. Inventando la nación. México: Fondo de Cultura Económica.

Rodríguez, J. (2005). La independencia de La América española. México: Fondo de Cultura Económica, El Colegio de México.

Rodríguez, J. (2007). 'La disputa por una hegemonía nacionalista: el 16 o 27 de septiembre como celebración de la 
fiesta nacional.' En Girón, N. (Coord.) La construcción del discurso nacional en México, un anhelo persistente (siglos XIX y XX). México: Instituto Mora.

Smith, A. (1997). La identidad nacional. Madrid: Trama editorial.

Smith, A. (2000). ¿ ¿Gastronomía o geología? El rol del nacionalismo en la reconstrucción de las naciones. En Bravo Fernández, A. (Comp.) La invención de la nación. Lecturas de la identidad de Herder a Homi Bhabha. Buenos Aires: Manantial.
Van Young, E. (2010). La otra rebelión. La lucha por la independencia de México, 1810-1821. México: Fondo de Cultura Económica.

Zermeño Padilla, G. (2009). 'Apropiación del pasado, escritura de la historia y construcción de la nación en México'. En Palacios, G. La nación y su historia. Independencias, relato historiográfico y debates sobre la nación: América Latina, siglo XIX. México: El Colegio de México. 